\title{
Ethnographic Study of the Community of Ecological Village, Temas Village, Batu City as a Source of Social Studies Learning
}

\author{
Ali Nasith ${ }^{\text {**, Waluyo Satrio Adji }}{ }^{2}$, Abdul Bashith ${ }^{3}$, Saiful Amin ${ }^{4}$ \\ ${ }_{1,2,4}$ Department of Social Science Education \\ ${ }^{2,3}$ Department of Madrasah Ibtidaiyah Teacher Education, \\ Faculty of Tarbiyah and Teacher Training, \\ Maulana Malik Ibrahim State Islamic University, Jalan Gajayana No.50 Malang, Indonesia \\ 1alinasith@gmail.com
}

\begin{abstract}
Cultivating the values of ecological wisdom in fostering a love for the environment through social studies learning is so important today because it can provide solutions to the negative impact of human anthropocentric views and provide insight into the nation's culture's knowledge. This research aims to provide a cultural description of the ecological village community groups who have local wisdom in the environment. The value of local knowledge is internalized in social studies learning to build a harmonious relationship between humans and nature. This study uses a qualitative approach to a new ethnographic type. Subjects are vital informants in the ecological village community. The results showed that the ecological village community had local wisdom, including socio-cultural values, including helping each other ("gotong royong"), shame culture. Then the value of environmental care includes the value of environmental sustainability, education, and waste management. The value of caring for the environment takes organic farming system activities, prohibitions raising roads, environmental planning patterns, healthy bazaar activities for waste bank management, and hand skills in utilizing waste. This study's considerations can be a reference or as a source of sociocultural-based social studies learning at various levels of formal, non-formal, and informal education.
\end{abstract}

Keywords

Ethnography, Ecological Wisdom, Ecological Village, Social Studies Learning.

Article Received: 10 August 2020, Revised: 25 October 2020, Accepted: 18 November 2020

\section{Introduction}

In the National Education System Law, Yulia Siska stated that the main objective of social studies education at the elementary school level is to develop the ability of students to have the sensitivity to every social problem, be able to be optimistic about social issues and be trained to provide solutions to solve the social issues [1].

In line with the objectives of social studies learning, Susanto stated that the goal of social studies is to develop self-potential and the structure of knowledge and reflect on the life of the nation and state [2]. Although different editors have the same thing, the two views have the same thing in shaping humans who have social characteristics.

In the process of building social character at the level of education, there are many problems, such as teachers not fully involving students in the learning process or using teacher-centered, learning is limited to remembering the material that has been taught, learning that is not meaningful, assuming science is more useful than social studies, and stigma. negative, there is no practical benefit from social studies learning [2]. This makes students who take social studies less enthusiastic, bored, sleepy, and have malicious behavior that shows rejection in learning social studies.

The bridge to overcome this is to raise social culture in the classroom to provide meaning and benefits to students. The success of social studies learning when contextualizing social culture has been proven in several studies; it was found that students were more enthusiastic and familiar with local culture, students' interest and passion for learning had increased, teachers and books were no longer the primary sources of learning [3], [4]. Environmental issues are so crucial today because the development of human and ecological interactions is increasingly contradicting. The pretext of fulfilling needs becomes the legitimacy to explore and even overexploit nature. Van Pursen stated that humans in the early stages of humans perceive nature as a significant force so that in this early stage in the event of an earthquake, wind, landslide, nature can be sure to be angry with humans. In the second stage, humans have begun to explain why landslides, 
floods, and natural turmoil occur. Developed to the last scene that humans have started to function nature according to human will [5].

In households in the City of Tarakan, domestic waste for some people living on the riverbanks indirectly decreases the quality of water in the river. This is caused by people who do not want to manage domestic waste such as chicken manure, used soap water, cooking leftovers, and food. This direct disposal behavior has resulted in a river water quality crisis [6]. Gold mining in small businesses with amalgamation in Krueng Sabee is contaminated by the introduction of mercury $(\mathrm{Hg})$, which harms human growth and the environment in general. The quality of water and fish contaminated with mercury also directly impacts humans, which can be seen from human hair [7]. Today's local culture is not only related to the cultural inheritance of our ancestors, but local culture can also be formed from social problems, especially those related to environmental crises. A collection of people in an area called a village can also develop their own culture to overcome the ecological crisis; this is done in the ecological village of Temas Village.

At the initial observation of the problem, it was felt by residents of the ecological village, administratively called RW (Small community include 10 RT) 06, that they realized that bad relations with nature must be repaired; the form starts with RT (Small community include 40 households) 01 with the awareness of trying to intensify planting in the sphere of the house first then the arrangement of plants and cleanliness in the alley, to improve relations with nature. Then the RT under the coordination of RW 06 tried to follow the steps taken by RT 01 .

The characteristics of the ecological village community have local wisdom that is closely related to the environment. The form of local wisdom is visible or tangible and invisible or intangible. Tangibles such as house arrangement, organic planting patterns, waste management patterns, and intangibles are advice to protect the environment. Local wisdom in ecological villages is oriented towards ecological values that have developed since long ago made people in their ideas and behavior preserve the environment.

The aims of this study is to find the values of a community group's local wisdom in maintaining a sustainable environment. Henceforth, the value in ecological wisdom is internalized in social studies learning to pass on values to build a harmonious relationship between humans and nature.

\section{RESEARCH METHODS}

The aim is to explore the values that exist in the Temas village community, who have been living there until now, especially in the concept of their ecological village. Hence, the basis of research uses a qualitative approach with a new ethnographic method. Sugiyono stated that: "qualitative research is the method used for objects with natural conditions; researchers have a central role, triangulation, analysis of the nature of inductive data, and research results are inclined toward meaning"[8].

In practical terms, researchers deeply mingle with the whole and natural atmosphere needed to understand a culture. In this study, researchers associated directly in the community of Temas Batu Village. In cultural research, it is a must in mingling with society with the aim that the accuracy of the data obtained can be maintained. Sugiyono [9] stated that: "There are traditional research types, namely phenomenological research, biographies, grounded theory, ethnographic studies, and case studies. The new ethnographic method was chosen because the ecological village's existing culture was the community's answer to environmental problems." This study's subjects were initiators of ecological villages, heads of RW, community leaders, heads of sub-districts, and communities. At the same time, the research location of the Ecological Village of Temas Village has a strategic side for the development of social studies learning resources.

Data analysis, the process of collecting data systematically to simplify the researcher to get a conclusion, is a data analysis technique. Miles and Huberman [10] stated that: "There are three posts, namely: reduction, presentation, conclusion. Data validation, an essential stage in research is data validation. The purpose of verification is to prove that the situation in the field can explain something being studied. For this purpose, the researcher checks the validity of the data by using data triangulation." 


\section{RESULTS AND DISCUSSION}

\section{Population Condition}

The total population in the Ecological village per 2016 was 1,331 people consisting of 369 families spread across 6 RT. Details can be seen as follows (Table 1).

Table 1. Profile of RW 06 in 2016

\begin{tabular}{|l|l|l|}
\hline RT & Total Soul & Head of Family \\
\hline RT 01 & 189 & 53 \\
\hline RT 02 & 269 & 61 \\
\hline RT 03 & 226 & 66 \\
\hline RT 04 & 220 & 74 \\
\hline RT 05 & 245 & 69 \\
\hline RT 06 & 182 & 46 \\
\hline Total & 1331 & 369 \\
\hline
\end{tabular}

Source: Profile of RW 06 in 2016

In the livelihood source for residents in ecological villages, $52 \%$ of households work as coolies, small food vendors, etc. Work like a farmer in 3\% of households.

Judging from the population's livelihood structure, most people in RW 06 , namely $52 \%$ of the total family heads (KK), work as porters, sellers of snacks / fried food, etc. Meanwhile, only 3\% of the whole family heads (KK) make their living as farmers. This is reinforced by the data on the area of RW 06, which is used for agricultural land, which is only about $25 \%$ of the total land area. The following is the number of household heads by livelihood:

Table 2. Type of Occupation for Residents of RW 06

\begin{tabular}{|l|l|}
\hline Type of Work & Number of households \\
\hline $\begin{array}{l}\text { Porters, snack } \\
\text { vendors, etc. }\end{array}$ & 194 \\
\hline $\begin{array}{l}\text { Private } \\
\text { Employees }\end{array}$ & 56 \\
\hline Entrepreneur & 40 \\
\hline $\begin{array}{l}\text { Construction } \\
\text { Worker }\end{array}$ & 34 \\
\hline Civil Servants & 22 \\
\hline Farmer & 13 \\
\hline Driver & 10 \\
\hline
\end{tabular}

\section{History of Ecological Village}

The initial form of the ecological village was started from RT 01 with the awareness of intensifying planting in the home area first, then the arrangement of plants and cleanliness in the alley, to present beauty in the dynamics of problems in Kota Wisata. Then the RT under the coordination of RW 06 tried to follow the steps taken by RT 01. In 2014/2015, the Head of Temas Village, Mr. Adit, held a village-level cleaning competition attended by all RWs under Temas Village. Because from the beginning, they had social capital to restore the village's beauty, finally through the ecological town competition village became the champion in the cleanliness competition.

\section{Ecological Wisdom Values in Ecological Villages}

Ecological wisdom in ecological villages in interacting with the environment is reflected in the values embodied in agricultural activities, greening patterns of house yards, waste management, handicrafts thematic alleys, and RW 06 healthy bazaar.

\section{Organic Farming System}

The problem that occurs today is that the existing planting system uses a lot of chemicals; in the short term, it benefits farmers because the planted plants grow quickly but in the long run, have an impact on soil quality [12]. The solution from farmers is that if the agricultural land is planted but cannot grow if diagnosed, it means the nutrients from the soil have been lost.

Farmers who were farming with an organic system sustainably, indirectly implementing cultural values. Based on experience, the farmers' head said that there are three values contained in an organic system, including honesty, commitment, and patience. Openness is manifested in the pattern of communication with family and society. Wherever they go, they communicate first. Commitment was manifested in leadership when he served as chairman of the RW.

Furthermore, in organic system agriculture, if there are problems, it is necessary to diagnose the location of the problem.

As head of the farmer group, he emphasized several things that are needed to be considered in 
crop management: (1) Land conditions. Many of the farmers wanted an organic farming system. Still, there was a failure in plant growth at the beginning, if the planted land previously had been used. Or made land with a touch of chemicals that finished the plants. Conservation that casted for 13 years, depending on the land conditions, is the key to regenerating land to become fertile and suitable for planting organic systems. (2) The use of fertilizers and soil fertilizers must go with the soil if the soil conditions are of small nutrients. It is necessary to treat them, such as applying fertilizers, in giving fertilizers the farmers must choose natural fertilizers such as compost from waste management. (3) Irrigation, irrigation only uses water in from the rivers and rainwater. Water purity should be noted that water is not contaminated with heavy materials. (4) Organic Agriculture Certification, Products from processed organic agriculture is known as life, and SOT/Temas organic vegetables are currently being traded and in demand. In the Be Life brand, there are partners from the Faculty of Agriculture, University of Brawijaya, to regulate and distribute every product that is traded with a valid certificate for five years. This needs to be renewed.

The focus on organic requirements is by research based on the SNI (Indonesian National Standard) 6729: 2016 standard in the Mekar Tani Jaya Farmer group that organic farming pays attention to conservation of land conditions, maintenance of organic land during the conversion period, management of organic products, Contamination Prevention, Land Management, Plant Selection, Management Ecosystem, Management of Plant Pest Organisms (OPT).

The problems faced are similar, namely that not all aspects of organic farming systems can be applied in a region because it will impact the other elements [13]. The difference is that organic land maintenance in the Mekar Jaya farmer group still alternates with the conventional system. Still, the ground in the ecological village is $100 \%$ for the organic system.

\section{Greening pattern in the yard}

The greening pattern is intended for beauty in every RW06 resident's house. For this reason, every citizen is encouraged to plant or maintain, initially the appeal is to take part in the competition together. However, because of the people's mindset that it is okay not to win the competition, since every house has an investment in plants, so over time, residents have begun to realize the vital role of plant maintenance.

The pattern of keeping it beautiful or green; residents use a culture of shame in every activity related to environmental conservation. If there are residents who still do not heed social punishment, the village apparatus will warn. This is different from the pattern of preserving sustainability from the ancestors' advice or in the form of occultism that exists in several regions in Indonesia [14].

\section{Waste Management Pattern}

The management of the "Waste Bank" is carried out by volunteers consisting of PKK (Housewives community) RW 06, who are directly appointed by representatives of the Batu City Environmental Service, four managers comprised of the Chairman, Deputy Chairperson, Secretary, and Treasurer. There are two types of waste managed by the Waste Bank Volunteers, namely nonorganic and organic waste.

The collection of waste in the Ecology Village Garbage Bank is taken by the Environmental Agency and is followed up by purchasing the nonorganic waste according to the agreed nominal criteria.

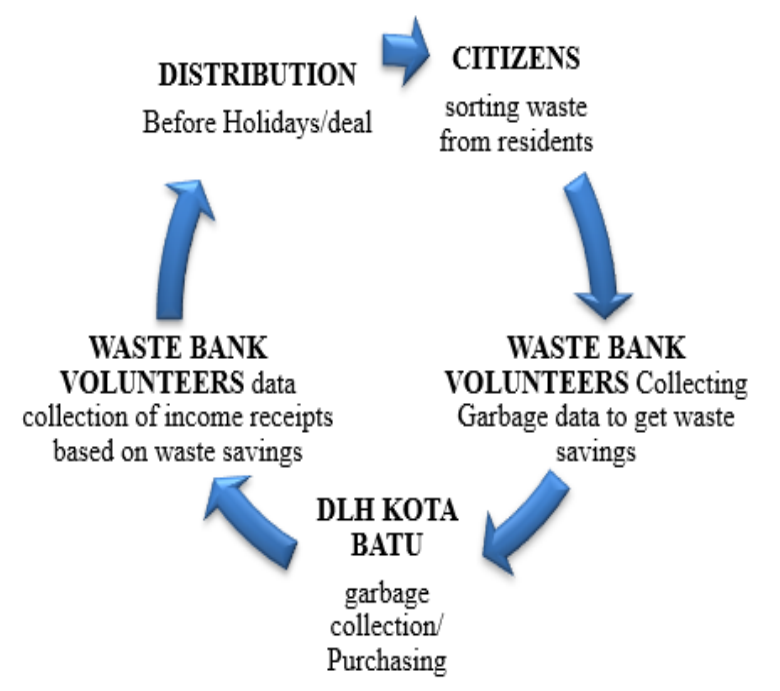

Figure 1. Research Frame work of Organic Waste Bank Cycle 


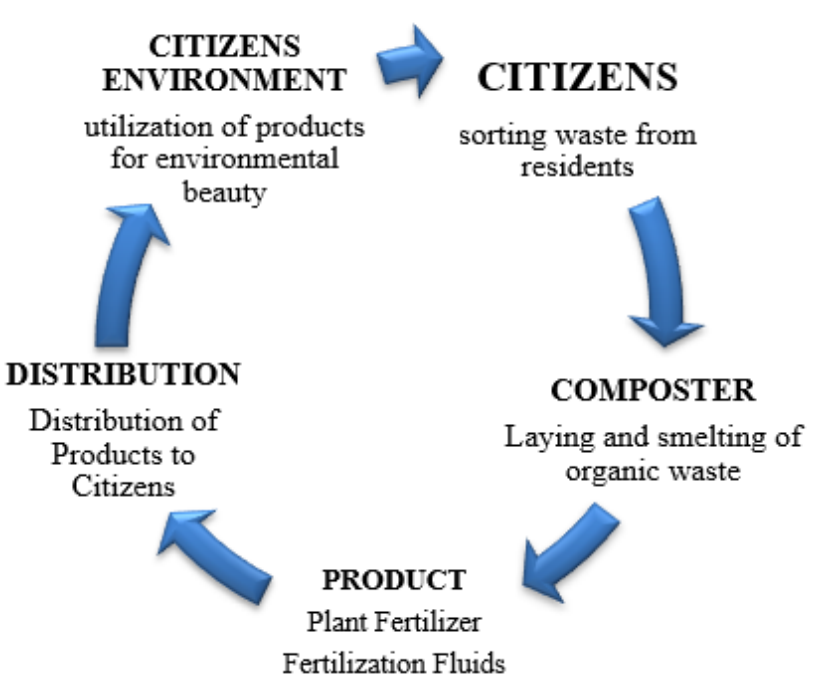

Figure 1. Research Frame work of nonOrganic Waste Bank Cycle

Bea Johnson introduced waste management with the 5R principle, namely Reduce, Reuse, Recycle, Replant, and Replace. The idea of regulating household waste management can be sorted and selected to minimize waste accumulation [15]. Long before the $5 \mathrm{R}$ concept, the ecological village community had independently managed waste but did not fully comply with the 5R concept.

Socialization is the initial stage of household waste management before saving it to a waste bank. The $3 \mathrm{R}$ principle in waste management is carried out in ecological villages, namely Reduce, Reuse, and Recycle.

The lack of awareness on the Replace and Replant aspects is due to the absence of a deep understanding of waste management. The greater the knowledge of an event, the more attention is awakened in a person [16].

The implementation of 5R is not entirely fulfilled. It is also found in Sukoharjo where household waste production is large, but the waste selection is still a problem because of the lack of awareness and participation of residents in waste management [17]. If awareness is formed of alternatives, the problem of applying the replace principle can be resolved, such as on the Eid alAdha in the Jakarta area providing an alternative to plastic bags, namely with baskets, loads of sweet potatoes, and banana leaves [18].

\section{Handycraft}

The initial point of view that waste can be useful and even prosperous is the key to making every handicraft in the ecological village. Regarding the initial mindset, it has a very positive and significant effect on motivation [19].

There are several reasons for choosing waste as an ingredient, namely because the material is easy and cheap to obtain. The most important is that it is the contribution of citizens to the environment. The various forms of waste are inspirations in the craftsmanship process, apart from the themes that are followed in an exhibition.

Since 2019, ecological village managers have developed the skills they have created, namely, eco print. Eco print is batik made from natural colors, namely leaves that have sap. There are two techniques developed in the management process, namely the foundation technique and the streaming technique. The pounding method is a batik technique by placing a leaf on the cloth and then beat it until the fibers and sap stick to the fabric. The foundation technique in ecological villages has not yet reached the use of lime, alum, and Tanjung fixators, which make the final results visible to the motifs and colors of the leave [20].

The steaming technique is a batik technique by tying the leaves and cloth, then steaming it for 2 3 hours. If a fixator can be used in the foundation technique, in the steaming method, the batik sasirange is close to that which is typical of South Kalimantan. The difference is in the coloring if Sasirangan uses Indigosol, which is a type of synthetic dye [21]. While the original eco print "batik" is from nature [22].

The impact of waste management into handicrafts with sale value is felt by the people who make handicrafts. In practice, this perspective on waste yields results in the form of citizen awareness of the 5R principles, namely Reduce, Reuse, Recycle, Replant, Replace. In reducing and replacing, residents become aware of the use of waste. This can be seen from most residents who replace plastic bags with bags made of cloth that can be used repeatedly. The emergence of an awareness of this is in line with what the field service team did to residents of RW 01, Wonosari Ngaliyan Village, namely that there has been a change in waste utilization [23].

\section{"Lorong Tematik"}

"Lorong Tematik" is an alley in an ecological village with a design following an agreed-upon theme. In its history, the thematic hallway originated from an idea sparked by the secretariat of RW 06. The determination of the composition 
was not absolute from the original originator but was discussed with the residents. This was to instill the value of togetherness and ownership of each existing design, but over time the concept of the theme in the alley adjusted with the vision of an ecological village.

The names of unique alleys include the love alley, the pundit alley, the space alley, the sun alley, the TPQ alley, and the happy alley. Between the aisles are decorated with various types of plants with plastic pot containers and the like to be placed in every corner, wall, and hung on the alley ceiling. Each person who enters the alley's educational element is a description of what objects are in the thematic hallway. The paintings that are painted on the walls initially followed the residents' agreement. Then images were made with big themes about ecology-going green, anti-pollution, saving energy, and positive words related to ecological wisdom.

\section{Healthy Bazaar}

The healthy bazaar in an ecological village is like a traditional bazaar, selling goods. The uniqueness can be found in the contents of the items being sold and the educational activities therein. Goods are sold from the community's interests in ecological villages, such as vegetables, handicraft items, and non-MSG dishes, besides educational activities in the form of training such as consultations on waste management, hand skills in managing waste, recipes for cooking healthy food, governance around organic farming.

The contribution of healthy bazaar activity has an impact on improving the quality of life of the residents. From not understanding ecological wisdom such as making crafts from waste, the knowledge of the residents in doing works is gradually improved. Improving the quality of life is a real impact of passing on ecological values that exist in ecological village communities.

\section{CONCLUSION}

Ecological village communities have local wisdom values, including socio-cultural values and environmental care values. Socio-cultural values exist in "gotong royong" and shame culture. The value of environmental preservation is in the form of organic farming system activities, greening patterns in the yard, healthy bazaar activities in waste bank management, and skills in utilizing waste. It is hoped that local wisdom values in ecological camps can be used as a reference as a source of social studies learning. Social studies' limitations only from books and teachers can be overcome by using learning sources from local wisdom in the local community.

\section{REFERENCES}

[1] Y. Siska, Pembelajaran IPS di SD/MI. Garudhawaca, 2018.

[2] A. Susanto, Pengembangan Pembelajaran IPS di SD. Kencana, 2014.

[3] E. H. Widiastuti, "Pemanfaatan Lingkungan Sebagai Sumber Pembelajaran Mata Pelajaran Ips," Satya Widya, vol. 33, no. $1, \quad$ p. 29, 2017, doi: 10.24246/j.sw.2017.v33.i1.p29-36.

[4] A. Efendi, "IMPLEMENTASI KEARIFAN BUDAYA LOKAL PADA MASYARAKAT ADAT KAMPUNG KUTA SEBAGAI SUMBER PEMBELAJARAN IPS," SOSIO Didakt. Soc. Sci. Educ. J., vol. 1, no. 2, Dec. 2014, doi: $10.15408 /$ sd.v1i2.1263.

[5] C. A. van Peursen, C. A. P. D. Peursen, and D. Hartoko, Strategi Kebudayaan <Edisi Baru>. Kanisius, 2000.

[6] I. Puspita, L. Ibrahim, and D. Hartono, "Penurunan Kualitas Air Sungai Karang Anyar Kota Tarakan ( Influence of The Behavior of Citizens Residing in Riverbanks to The Decrease of Water Quality in The River of Karang Anyar Tarakan City )," J. Mns. dan Lingkung., vol. 23, no. 2, pp. 249-258, 2016, doi: https://doi.org/10.22146/jml.18797.

[7] S. Sofia and A. H. Husodo, "Kontaminasi Merkuri Pada Sampel Lingkungan Dan Faktor Risiko Pada Masyarakat Dari Kegiatan Penambangan Emas Skala Kecil Krueng Sabee Provinsi Aceh (Mercury Contamination in the Environmental Samples and Risk Factors in Inhabitants of the Small Scale Gold)," J. Mns. dan Lingkung., vol. 23, no. 3, p. 310, Feb. 2017, doi: 10.22146/jml.18803.

[8] Sugiyono, Metode Penelitian Kuantitatif, Kualitatif dan R \& D.Bandung:Alfabeta. 2012.

[9] J. W. Creswell, Qualitative Inquiry and Research Design (Choosing Among 5 Approaches). 2007. 
[10] M. B. Miles and ;A Michael Huberman, "An Expanded Sourcebook Qualitative Data Analysis," Archives of Gynecology and Obstetrics. 1992, doi: 10.1007/BF02759913.

[11] R. Anita, "Tipologi Modal Sosial Dalam Pengembangan Kampung Ekologi Batu Into Green Kelurahan Temas Kota Batu," Aug. 2017.

[12] M. muslimah Muslimah, "DAMPAK PENCEMARAN TANAH DAN LANGKAH PENCEGAHAN," J. Penelit. Agrisamudra, vol. 2, no. 1, pp. 11-20, Oct. 2017, doi: 10.33059/jpas.v2i1.224.

[13] F. Imani, A. Charina, T. Karyani, and G. W. Mukti, "Penerapan Sistem Pertanian Organik Di Kelompok Tani Mekar Tani Jaya Desa Cibodas Kabupaten Bandung Barat," Mimb. AGRIBISNIS J. Pemikir. Masy. Ilm. Berwawasan Agribisnis, vol. 4, no. 2, p. 139, 2018, doi: 10.25157/ma.v4i2.1173.

[14] M. Holilah, "Kearifan Ekologis Budaya Lokal Masyarakat Adat Cigugur Sebagai Sumber Belajar Ips," J. Pendidik. Ilmu Sos., vol. 24, no. 2, p. 163, 2016, doi: 10.17509/jpis.v24i2.1453.

[15] J. Jud, "The 5 'R's' of Zero Waste: A Practical Guide | zerowasteXchange," 2017.

https://zerowastexchange.org/551/the-5-rsof-zero-waste-a-practical-guide (accessed Jul. 01, 2020).

[16] K. Amboro, "Membangun Kesadaran Berawal Dari Pemahaman; Relasi Pemahaman Sejarah Dengan Kesadaran Sejarah Mahasiswa Program Studi Pendidikan Sejarah Fkip Universitas Muhammadiyah Metro," Historia Santiago., vol. 3, no. 2, p. 109, 2015, doi: 10.24127/hj.v3i2.150.

[17] Margana and I. Aliyah, "Pusat Penelitian dan Pengembangan Pariwisata dan Budaya LPPM Universitas Sebelas Maret Surakarta Program Studi Perencanaan Wilayah dan Kota, Fakultas Teknik, Universitas Sebelas Maret Surakarta," no. $1,2015$.

[18] F. Nursaniyah, "Kurangi Penggunaan Kantong Plastik, Berikut 3 Alternatif Wadah Daging Kurban yang Dapat Digunakan - Pikiran Rakyat Bandung
Raya," Jul. $\quad 07, \quad 2020$. https://prbandungraya.pikiranrakyat.com/pendidikan/pr-

26587633/kurangi-penggunaan-kantongplastik-berikut-3-alternatif-wadah-dagingkurban-yang-dapat-digunakan (accessed Jul. 08, 2020).

[19] R. Lewenussa and H. Suaidy, "Pengaruh Pola Pikir (Mindset) Kewirausahaan Terhadap Motivasi Dan Keterampilan Wirausaha Mahasiswa Program Studi Manajemen Universitas Muhammadiyah Sorong," SENTRALISASI, vol. 8, no. 1, p. 1, Feb. 2019, doi: 10.33506/sl.v8i1.385.

[20] B. D. S. Wirawan and M. Alvin, "Teknik Pewarnaan Alam Eco Print Daun Ubi Dengan," J. Litbang Kota Pekalongan, vol. 17, pp. 1-5, 2019.

[21] E. S. Murwati, I. Kartika, and G. Briegel, "TEKNOLOGI PROSES SASIRANGAN DENGAN VARIASI TEKNIK JELUJUR Sasirangan Process with Baste Technique Variation." doi: http://dx.doi.org/10.22322/dkb.v31i0.1085 .g922.

[22] A.- Hading Kurniati; Abu, Asiani, "Pewarnaan Tumbuhan Alami Kain Sutera Dengan Menggunakan Fiksator Tawas, Tunjung Dan Kapur Tohor," Indones. J. Fundam. Sci., no. Vol 2, No 2 (2016), pp. 86-91, 2016, [Online]. Available: http://ojs.unm.ac.id/pinisi/article/view/243 0 .

[23] N. Fatoni, R. Imanuddin, and A. R. Darmawan, "Pendayagunaan Sampah Menjadi Produk Kerajinan," Dimas J. Pemikir. Agama untuk Pemberdaya., vol. 17, no. 1, p. 83, Jul. 2017, doi: 10.21580/dms.2017.171.1505. 